\title{
Current Understanding of the Chronobiology of Cluster Headache and the Role of Sleep in Its Management
}

This article was published in the following Dove Press journal: Nature and Science of Sleep

\author{
Mads Barloese $\mathbb{D}^{1,2}$ \\ 'Department of Clinical Physiology and \\ Nuclear Medicine, Center for Functional \\ and Diagnostic Imaging, Hvidovre \\ Hospital, Hvidovre, Denmark; \\ ${ }^{2}$ Department of Neurology, Danish \\ Headache Center, Rigshospitalet- \\ Glostrup, Glostrup, Denmark
}

\begin{abstract}
Cluster headache is uniquely rhythmic in its occurrence both diurnally and annually. This has implications for the clinical approach to the patient but also for our understanding of the role of central structures in its pathological basis. Many intrinsic and extrinsic factors seem to influence $\mathrm{CH}$ rhythmicity, including genetics. The proclivity for attacks to occur at night and the possible association with particular sleep phenomena, including sleep apnea, have motivated a number of studies which has improved our understanding but many questions remain unanswered. The sleep-headache interaction seems to be bidirectional and possibly both direct and indirect. The latter could involve more disperse networks of homeostatic regulation, which may better encompass recent observations. Treatment of the headache patient with concurrent sleep problems can be particularly challenging, especially considering side-effects and interactions of commonly used medications. While current treatment guidelines do not incorporate chronotherapeutic thinking, some evidence may suggest that application of such principles on an individual level may be beneficial.
\end{abstract}

Keywords: cluster headache, chronobiology, sleep, chronotherapy

\section{Introduction}

Cluster headache $(\mathrm{CH})$ is a primary headache disorder which constitutes a unique clinical challenge. Two attack features stand out: The extreme pain and predictability. The former has been described as worse than childbirth, extensive limb fracture and kidney stones ${ }^{1}$ and is included in the diagnostic criteria in The International Classification of Headache Disorders, $3^{\text {rd }}$ Edition, $^{2}$ (ICHD-3). The unilateral, 15-180 min attacks may occur from once every other day up to eight times daily and are accompanied by ipsilateral cranial autonomic symptoms such as lacrimation, rhinorrhea and conjunctival injection. $\mathrm{CH}$ is a trigeminal autonomic cephalalgia - an umbrella term for disorders with such commonalities of which $\mathrm{CH}$ has the highest prevalence, longest attack duration and lowest frequency. ${ }^{3} \mathrm{CH}$ patients can sometimes routinely predict attacks to the hour ${ }^{4}$ and attacks occur in week- or month-long clusters (hence the name), the presence and duration of which dichotomizes the disorder into episodic (eCH, longer attack free periods) and chronic (cCH, no meaningful attack free periods) $\mathrm{CH}$. This differentiation serves mainly to describe the burden with no known pathophysiological differences. There is a male predominance of around 2 to 1 , and debut in the third or fourth decade. ${ }^{5}$
Correspondence: Mads Barloese Funktions- Og Billeddiagnostisk Enhed, Hvidovre Hospital, Kettegaard Alle 30, Hvidovre, DK-2650, Denmark Email mbar0087@regionh.dk

Nature and Science of Sleep 2021:13 153-162 
Patients are heavily burdened by the disorder ${ }^{6}$ and the social and economic consequences are considerable. ${ }^{7,8}$

$\mathrm{CH}$ is sometimes characterized as a rare disorder with a prevalence of $0.1 \%{ }^{9}$ which is reflected in our understanding of the pathophysiology that in many areas remains speculative. Putative mechanisms revolve around pathological activation or disinhibition of the trigeminal autonomic reflex with involvement of the hypothalamus and other diencephalic and brainstem nuclei. This hinges on the relapsing-remitting nature and on the concept of $\mathrm{CH}$ as a sleep-related headache. ${ }^{10,11}$ Generally, headache and sleep amalgamate clinically, physiologically and anatomically ${ }^{12-17}$ but $\mathrm{CH}$ is likely the primary headache disorder with the closest relationship with sleep exempting the exceedingly rare hypnic headache.

It is easy to portray $\mathrm{CH}$ as a somewhat enigmatic condition with limited therapeutic options and many unand misdiagnosed cases. However, the last three decades have seen some progress in therapeutics and in our understanding of the disorder. Still, studying sleep, headache and chronobiology is difficult, time-consuming and requires expertise. Few groups have undertaken the combined endeavor but recent results justify a combined look at the rhythmicity of the disorder which is the aim of this narrative review. These topics will be covered below and put into context of the clinical approach to the $\mathrm{CH}$ patient.

\section{Chronobiology}

Other neurological disorders also have chronobiological elements ${ }^{18}$ but arguably not as pronounced as $\mathrm{CH}$ where the prevalence of retrospectively, self-reported diurnal rhythmicity is around $60-80 \% .{ }^{19-22}$ Despite some variation, it is a highly reliable finding also described in historical accounts and across varying populations. ${ }^{23}$ Studies in the eighties showed clear hours of increased attack occurrence, possibly associated with sleep, and recurring clusters around the solstices in June and December. ${ }^{24,25}$ These findings corroborated earlier reports showing a connection with relative states of activity and a proclivity for attacks to arise during times of relaxation. ${ }^{26-29}$

Modern studies of diurnal rhythmicity are mostly consistent. This author published findings from 351 patients showing that the most common time of attacks is around 1-2 a.m. ${ }^{30}$ The concept of chronorisk was also suggested to describe the attack patterns as this term may better encompass the multiple identified extrinsic and intrinsic factors

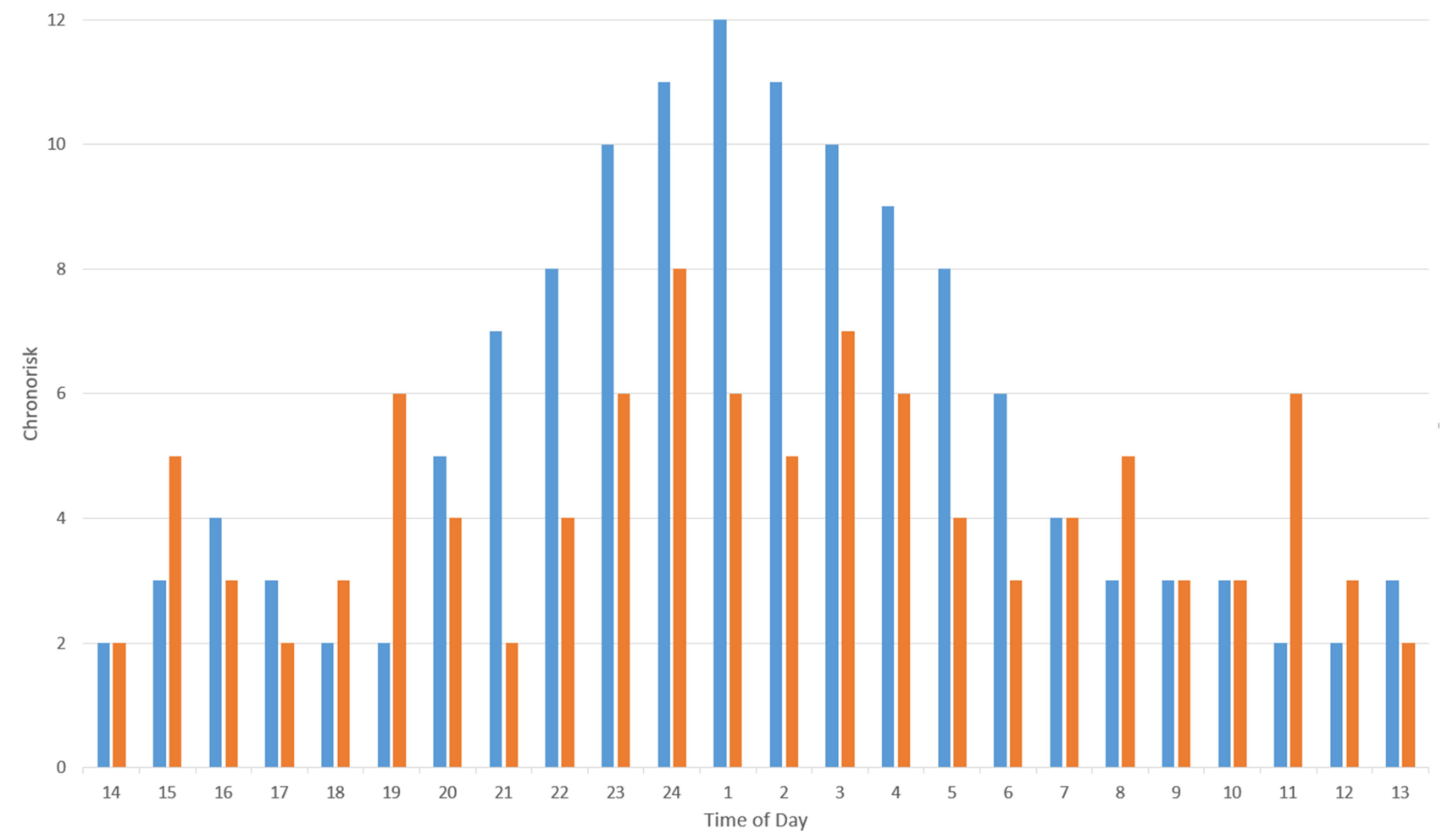

Figure I Representative chronorisk analysis of episodic (eCH, blue bars) and chronic $(\mathrm{cCH}$, orange bars) cluster headache patients showing peaks of chronorisk during the 24 hours of the day. Chronic patients have more peaks throughout the day indicating more ultradian oscillation in chronorisk compared to eCH. A detailed description of the methodology behind this analysis is available in references. ${ }^{30,36}$ 
affecting rhythmicity. For example, in men compared to women, chronorisk peaks appear to be phase-shifted forward, with the nocturnal peak occurring 1 hour earlier, at 1-2 a.m. vs 3 a.m., despite similar bed-times and chronotypes. ${ }^{5}$ Using signal-analysis methods, eCH patients have been shown to have much stronger circadian oscillations of chronorisk than $\mathrm{cCH}$ patients who have more prominent ultradian oscillations (Figure 1). ${ }^{30}$ Since the suprachiasmatic nucleus is responsible for generating near 24-hour rhythms, speculatively, this phenotype may result from diminished influence of this structure on other diencephalic and brainstem circuits in $\mathrm{cCH}$. This notion is partly supported by the differential treatment response to melatonin and lithium (enhances circadian PER2 protein rhythms ${ }^{31}$ ) in these patients. ${ }^{32-34}$

Annually, $\mathrm{CH}$ cluster occurrence has also been described to be predictable but studies have shown quite dissimilar results. ${ }^{19-21,24}$ However, with closer scrutiny, there does seem to be one commonality between these which is clinical improvement in the summer months. Otherwise, different patterns have been observed with clusters around the summer and winter solstice. ${ }^{24}$ It was speculated that at these times of the year, with the maximum difference in the duration of night and day, lacking entrainment somehow results in a destabilization of the suprachiasmatic nucleus (SCN) leading to cluster penetrance. Two other studies have shown worsening in the spring and fall ${ }^{19,20}$ and a fourth have shown worsening in fall, winter and spring (Figure 2). ${ }^{21}$ The latter suggested a relationship with hours of daylight since cluster activity was lowest during the brighter months of the year.
Another feature of $\mathrm{CH}$ rhythmicity is that it seems nonstatic with some inter- and intra-individual variation. ${ }^{22}$ However, with disease progression, there seems to be a trend from randomness towards consolidation into nocturnal and midday attacks. This highlights a weakness in cross-sectional studies where individual variability cannot emerge. Another outstanding issue is that of rhythmicity with a phase longer than 24 hours (infradian) which can only be addressed through prospective recording which hitherto has not been undertaken on a large scale.

A genetic component in $\mathrm{CH}$ is supported epidemiologically and ties in with the strong chronobiological features. $^{35,36}$ Remarkably, it has been shown that in familial $\mathrm{CH}$, relative nocturnal chronorisk is more than double that of sporadic $\mathrm{CH}^{36}$ Three possible culprit genes, which pertain to the topic of this review, have been identified. ${ }^{35,37,38}$ First, a genetic polymorphism of the $C L O C K$ (Circadian Locomotor Output Cycles Kaput) was recently found to be associated with $\mathrm{CH}$. This signal strengthened after stratifying according to diurnal rhythmicity. ${ }^{39}$ Second, a possible, albeit contended, association with the hypocretin (also known as orexin) 2 receptor gene has been suggested which together with the finding of lower CSF-hypocretin levels ${ }^{40}$ implicate this system in $\mathrm{CH}$ pathology (discussed further below). ${ }^{41-44}$ Lastly, the parasympathetic and hypothalamic signaling molecule pituitary adenylate cyclaseactivating peptide (PACAP) represents another point of confluence between sleep, trigeminal-vascular coupling and chronoregulation and has garnered considerable

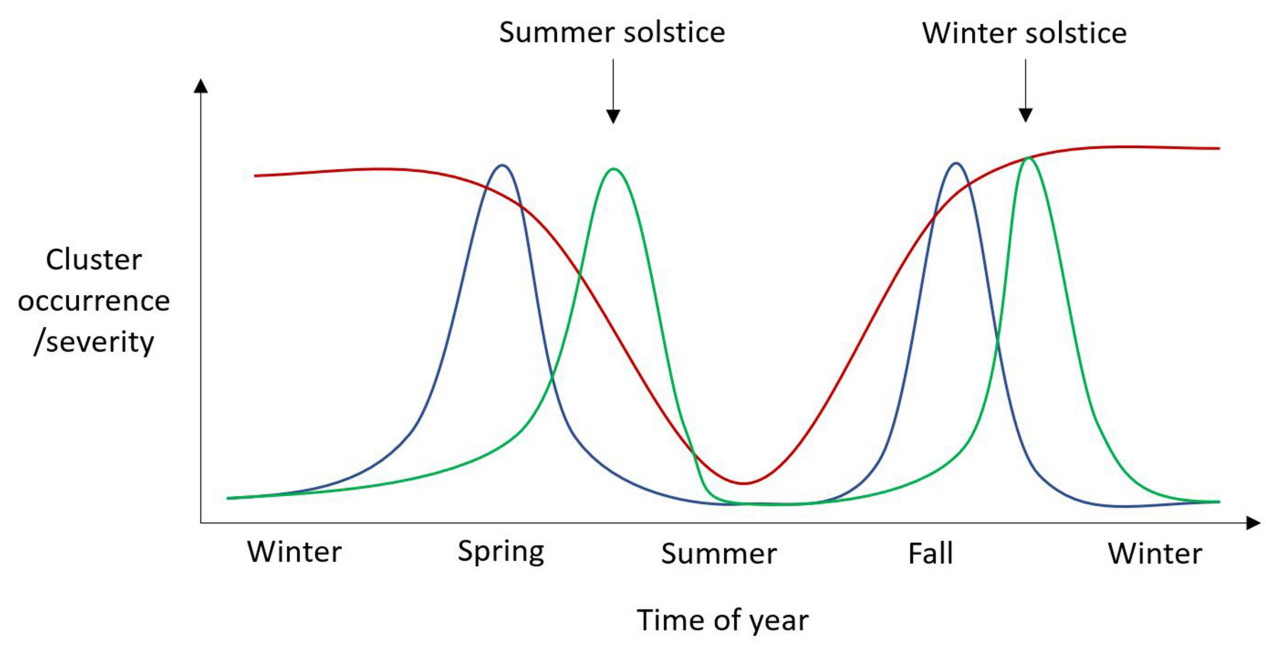

Figure 2 Schematic representation of three possible annual patterns of cluster occurrence/severity. Red line - cluster occurrence/severity improves during the summer months, possibly due to number of daylight hours. Blue line - Clusters occur during the spring and autumn months. Green line - clusters occur around the time of the solstices, possibly due to an inability to synchronize the internal circannual pacemaker. 
interest. ${ }^{45} \mathrm{~A}$ genetic study has shown an association between the PACAP receptor gene and $\mathrm{CH}^{46}$ but decisive findings are still lacking. ${ }^{47,48}$

\section{Sleep in Cluster Headache}

Sleep and headache are entwined which is especially true for $\mathrm{CH} .{ }^{15}$ Nocturnal attacks result in a direct perturbation of sleep, but there is also evidence of an indirect, bidirectional interaction. Sleep as a trigger of attacks is reported by $80 \%$ of patients and napping by $30 \% .{ }^{21}$ Subjective sleep quality is reduced in $\mathrm{CH}$, both in the cluster period and outside ${ }^{21}$ and insomnia is also frequently reported. ${ }^{20,49}$ Anecdotally, nighttime attacks may be averted by skipping the night's sleep. ${ }^{50}$ Such findings and observations have justified a number of polysomnographic studies in $\mathrm{CH}$. Generally, these are quite heterogenous, mostly uncontrolled, of limited size with only few observed attacks during full polysomnography. The hypotheses in these studies have been an association between $\mathrm{CH}$ and REM-sleep and sleep apnea. ${ }^{51}$

That $\mathrm{CH}$ is somehow associated with REM-sleep is suggested by the reported proclivity of the attacks for arising 90 min after sleep onset and the basic assumption that this coincides with the first REM-phase. ${ }^{21,25,52}$ Early sleep studies confirmed this with the differentiation that it is only $\mathrm{eCH}$-, and not $\mathrm{cCH}$-attacks that show this tendency. ${ }^{53,54}$ However, a 1991 case report with multiple

Table I Observed Nocturnal Cluster Headache Attacks

\begin{tabular}{|c|c|c|c|}
\hline & \multirow[b]{2}{*}{ Diagnosis (n) } & \multicolumn{2}{|c|}{ Attacks Arising from } \\
\hline & & REM & Non-REM \\
\hline Dexter et Weitzman ${ }^{53}$ & eCH (3) & 5 & 4 \\
\hline Pfaffenrath et $\mathrm{al}^{56}$ & $\mathrm{cCH}(9)$ & 5 & 17 \\
\hline Nobre et $\mathrm{al}^{59}$ & $\mathrm{eCH}(37)$ & 2 & 0 \\
\hline Della Marca et al ${ }^{60}$ & $\mathrm{eCH}(\mathrm{I})$ & 2 & 0 \\
\hline Terzaghi et $\mathrm{al}^{58}$ & $\mathrm{eCH}(7)$ & I & 4 \\
\hline Zaremba et $a^{61}$ & $\mathrm{eCH}(2)$ & 0 & 8 \\
\hline Zaremba et $\mathrm{al}^{61}$ & $\mathrm{cCH}(3)$ & 0 & 8 \\
\hline Barloese et $\mathrm{al}^{57}$ & $\mathrm{eCH}(20)$ & 9 & 15 \\
\hline \multirow[t]{4}{*}{ Barloese et $\mathrm{al}^{57}$} & $\mathrm{cCH}(\mathrm{I})$ & 2 & 6 \\
\hline & Total & $26(30 \%)$ & $62(70 \%)$ \\
\hline & $\mathrm{cCH}$ & $7(18 \%)$ & 31 (82\%) \\
\hline & $\mathrm{eCH}$ & $19(38 \%)$ & 31 (62\%) \\
\hline
\end{tabular}

sleep investigations in an $\mathrm{eCH}$ patient with narcolepsy with cataplexy sowed doubt with regards to any REMassociation as there was no attack preponderance during the sleep-onset and excessive REM sleep characteristic of this sleep disorder. ${ }^{55}$ Later studies added to this doubt, ${ }^{56-58}$ although a simple tally of all reported attacks does in fact show a numerical overrepresentation of $\mathrm{eCH}$ attacks arising from REM-sleep, assuming that this stage makes up around $17 \%$ of total sleep time ${ }^{57}$ in these patients (Table 1). However, REM-sleep cannot be a prerequisite as in these studies attacks have also been observed arising out of other stages in the same patients. This has led to the hypothesis that it is rather the end or beginning of sleep cycles that is vulnerable. ${ }^{57} \mathrm{cCH}$ patients trend towards more fragmented sleep, shorter total sleep time, longer REM-latency and more limb movement ${ }^{56,57}$ and this less consolidated sleep pattern could explain why nocturnal attacks here are more randomly distributed. $\mathrm{CH}$ attacks have also been reported to arise at times of parasympathetic dominance or during times of shifting towards parasympathetic dominance from relative sympathetic dominance which may be the common factor between day- and nighttime attacks. ${ }^{21,26}$ This could explain why spontaneous attacks are sparse during investigations as patients may be apprehensive due to the setting of an in-hospital investigation.

Sleep apnea is one of the most studied aspects of $\mathrm{CH}$ and a long-debated topic. The disorder encompasses the partial or complete cessation of breathing during sleep due to anatomical and neuromuscular factors. ${ }^{62}$ Obstructive sleep apnea has a prevalence of $2-14 \%$ but in patients being investigated for sleep disturbances it may increase to $20-90 \% .{ }^{63}$ Whether there is coincidental coexistence in populations with overlapping predisposing factors or a causal relationship with $\mathrm{CH}$ remains unresolved. A possible pathological correlate does exist in the form of disturbed autonomic homeostasis, ${ }^{64}$ perhaps stemming from dysregulated or suppressed hypothalamic function. ${ }^{65}$

In mainly uncontrolled studies, using different methodologies and definitions, the prevalence of sleep apnea in $\mathrm{CH}$ has been reported to approach $80 \%{ }^{54,59,66-69}$ One controlled study found increased occurrence in $\mathrm{CH}$ patients (29\%) compared to age-, sex- and BMI-matched controls $(7 \%)$ and a possible association with the cluster periods. ${ }^{70}$ Reports of attacks being abolished by adequate treatment of sleep apnea and bruxism ${ }^{71-73}$ would certainly suggest a causal nature as would a possible temporal proximity between sleep apnea events and attacks. ${ }^{68}$ 
However, two controlled Danish studies, with overlapping populations, found no difference in presence of sleep apnea between patients and controls, no association between attacks and apnea events ${ }^{57}$ and no difference between the cluster and remission periods. ${ }^{74}$ The latter partly corroborating older findings ${ }^{69}$ Further, in 6 patients treated with CPAP, there was no certain effect on the occurrence of $\mathrm{CH}^{57}$ The matching to controls in these three studies may not be entirely adequate, unfortunately, as up to $80 \%$ of $\mathrm{CH}$ patients are current or past smokers. ${ }^{21,75}$ Smoking has been shown to worsen preexisting apneic tendencies through several pathways ${ }^{76}$ and strongly predicts sleep apnea after age and sleepiness. ${ }^{77}$

Here it is prudent to interject a distinction between $\mathrm{CH}$ and its possible association with sleep apnea and headache secondary to sleep apnea. The ICHD-3 deals with sleep apnea headache as a secondary headache (attributed to disorder of homeostasis) described as a morning headache with no accompanying features, bilateral in location, lasting under 4 hours and resolving with treatment of the sleep apnea. ${ }^{2}$ This obviously is not reminiscent of $\mathrm{CH}$ but whether $\mathrm{CH}$ still can be secondary to sleep apnea, or vice versa, remains undecided and possibly nosological. Whether one can exacerbate the other is also undecided since the severity of the described morning headaches may not be related to the severity of the sleep apnea. ${ }^{78-80}$ This may also pertain to other headaches and exacerbating and alleviating factors in general.

Lastly, the sleep disturbances in $\mathrm{CH}$ seemingly do not strictly follow a bout-remission pattern as does the headache attacks. This has been shown using subjective data where sleep quality, as measured using the Pittsburgh Sleep Quality Index, remained pathological up to 1 year after the last $\mathrm{CH}$ attack, a result which was reproduced across multiple subgroups without correlation to presence or absence of nocturnal attacks. ${ }^{21}$ This pattern was reproduced objectively. Compared to controls, $\mathrm{CH}$ patients have shorter total sleep time, reduced efficiency, longer sleep and REM-latency but there are no differences in these measures in- and outside of the cluster. ${ }^{74}$ Two models were proposed in which either a persisting, underlying pathology prevents sleep from normalizing outside of the cluster, or sleep normalization is a protracted process with a duration of a year or more. Overall, these findings support an indirect, complex relationship between $\mathrm{CH}$ and sleep.

\section{The Hypothalamus and Hypocretin}

Housing the organism's pacemaker, the attack rhythmicity of $\mathrm{CH}$ alone may implicate the hypothalamus and SCN. However, evidence for this particular structure's involvement in $\mathrm{CH}$ pathology is substantially stronger. Firstly, neuroimaging studies have shown mostly consistent structural changes as well as peri-ictal activation in the hypothalamus of $\mathrm{CH}$ patients. ${ }^{81,82}$ Secondly, several hormones controlled by the hypothalamus are affected ${ }^{83}$ including melatonin where the nocturnal melatonin peak is blunted and phase-shifted. ${ }^{84-86}$ This could result from desynchronization between internal and environmental cues ${ }^{83}$ altered autonomic functioning but changes could also be secondary to the direct effects on sleep of nocturnal attacks. Thirdly, findings of sleep- ${ }^{51}$ and autonomic alterations ${ }^{64}$ implicate the hypothalamus/diencephalon as a nexus of homeostatic control. Lastly, as discussed briefly above, DBS of the posterior hypothalamus is effective in some $\mathrm{CH}$ patients ${ }^{87}$ and its stimulation may influence both sleep $^{88,89}$ and rectify diminished sympathoexcitatory output in these patients. ${ }^{90}$ Based on these observations the role of the hypothalamus in $\mathrm{CH}$ pathology has been suggested to be 1) a primum movens, 2) as that which ends the attack or 3) as responsible for diminished descending antinociceptive control putting the implicated circuits in a permissive or attack-susceptible state.

Although the hypothalamus has not classically been considered part of the central pain processing network in the headaches it may play a significant role. It does have bidirectional connections with limbic structures, the raphe nuclei, periaqueductal gray, rostroventromedial medulla, and the solitary tract. A bidirectional trigeminohypothalamic tract has been identified ${ }^{91,92}$ and as an integrator of sensory information the hypothalamus in turn exerts descending control over the trigeminal cervical complex as well as the superior salivatory nucleus, the primary parasympathetic nucleus supplying the facial and cranial anatomy. ${ }^{93}$ Some of these projections have been identified as hypocretinergic. ${ }^{94,95}$ Thus, besides REM-sleep and apnea, this system could be a third possible point of convergence between $\mathrm{CH}$ and sleep. ${ }^{96}$ Hypocretin-1 and -2 has differential pro- and antinociceptive effects and has through CSF-measurements, animal studies and the genetic studies mentioned above been implicated in $\mathrm{CH}$ pathophysiology. ${ }^{40,97}$ Remarkably, hypocretin seems to exhibit seasonal variation inverse to the cluster pattern. ${ }^{21,98}$ Still, the causality of the observed alterations 
pointing towards hypothalamic dysregulation is undetermined and changes could well be secondary.

\section{Clinical Approach and Management}

$\mathrm{CH}$ is a uniquely chronobiological disorder which can be a substantial clinical challenge. While it remains hypothetical, the predictable nocturnal attacks, subclinical homeostatic disturbance and response to known chronotherapeutics implicate hypothalamic and diencephalic networks which engage in pathological interaction with trigeminal nociceptive processing. On this basis, attacks may worsen sleep and poor sleep may lead to more frequent attacks in a vicious circle.

$\mathrm{CH}$ is treated with a combination of acute, transitional and preventive measures. ${ }^{99}$ Acutely, patients use injectable triptans or $100 \%$ oxygen inhalation. To provide immediate, fast-acting, preventive relief glucocorticoids per os or greater occipital nerve blocks can prevent or weaken attacks before prophylactic medication is titrated to effective levels. Typically, patients are offered 200-1000 mg verapamil daily although lithium is also effective, primarily in $\mathrm{cCH}$. Recently, calcitonin gene-related peptide (CGRP) antibodies have become available and are effective in migraine ${ }^{100}$ and $\mathrm{eCH}^{101}$ but not $\mathrm{cCH} .{ }^{102}$ Invasive and non-invasive neuromodulation options are also available.

There are no treatment guidelines for $\mathrm{CH}$ which encompass sleep-related or chronobiological thinking ${ }^{99,103}$ which is remarkable considering that out of the eleven preventive medications which are considered at least possibly effective in $\mathrm{CH}$, four are known to manipulate molecular circadian feedback loops (melatonin, corticosteroids, lithium, valproic acid). ${ }^{4}$ However, preliminary reports suggest that there may be therapeutic gains in tailoring treatment to the individual chrono-profile of the patient. ${ }^{104}$ In one openlabel study, $52 \mathrm{ECH}$ and $18 \mathrm{CCH}$ patients were administered 200-960 mg daily of immediate-release verapamil to time maximum plasma concentration with peak individual chronorisk. Results were impressive with complete termination of attacks in $94 \%$ of eCH patients and $56 \%$ of cCH patients. These results have yet to be confirmed in controlled setups but none the less act as proof-of-concept.

Melatonin has been shown to have some efficacy in $\mathrm{eCH}$ but not $\mathrm{cCH}$ (level $\mathrm{C}$ recommendation). ${ }^{32}$ As stated above, sleep deprivation has anecdotal support ${ }^{50}$ and explorations of the therapeutic effect of bright light therapy may also be warranted considering the inverse relationship between cluster occurrence and daylight found in
Table 2 Frequently Used Headache Drugs and Their Possible Effect on Sleep

\begin{tabular}{|c|c|}
\hline Headache Drug & $\begin{array}{l}\text { Possible Sleep-Related Adverse Side- } \\
\text { Effects }\end{array}$ \\
\hline NSAIDs & $\begin{array}{l}\text { Dampens amplitude of nocturnal melatonin } \\
\text { Lowers sleep efficiency } \\
\text { Worsens sleep disordered breathing }\end{array}$ \\
\hline Triptans and ergots & $\begin{array}{l}\text { Somnolence } \\
\text { Decreases REM sleep }\end{array}$ \\
\hline $\begin{array}{l}\text { Serotonin } \\
\text { antagonists }\end{array}$ & $\begin{array}{l}\text { Increase wakefulness, reduces sleep } \\
\text { Insomnia } \\
\text { Boosts NREM sleep }\end{array}$ \\
\hline Beta-blockers & $\begin{array}{l}\text { Tiredness } \\
\text { Insomnia } \\
\text { Parasomnias and vivid dreams } \\
\text { Lower melatonin - reduced circadian signal }\end{array}$ \\
\hline Antidepressants & $\begin{array}{l}\text { Delayed REM-onset } \\
\text { Reduced REM-density } \\
\text { Increased sleep fragmentation } \\
\text { Worsens/induces RLS } \\
\text { Worsens/induces PLMD } \\
\text { Reduces dream recall }\end{array}$ \\
\hline Anticonvulsants & $\begin{array}{l}\text { Increased REM, reduced latency } \\
\text { Somnolence/Insomnia } \\
\text { Reduces RLS and PLMD }\end{array}$ \\
\hline Melatonin & $\begin{array}{l}\text { Increases sleep efficiency } \\
\text { Possible effect on REM density } \\
\text { Reduces symptoms of RBD } \\
\text { Phase shift }\end{array}$ \\
\hline Corticosteroids & $\begin{array}{l}\text { Insomnia } \\
\text { Reduces REM } \\
\text { Increases nocturnal awakenings }\end{array}$ \\
\hline Lithium & $\begin{array}{l}\text { Reduces REM } \\
\text { Enhances SWS } \\
\text { Phase lengthening } \\
\text { Enhances amplitude of circadian signal } \\
\text { Worsens RLS }\end{array}$ \\
\hline $\begin{array}{l}\text { Ca-channel } \\
\text { antagonists }\end{array}$ & $\begin{array}{l}\text { Drowsiness } \\
\text { Fatigue } \\
\text { Insomnia } \\
\text { Vivid dreaming }\end{array}$ \\
\hline Caffeine & Boosts SWS in second sleep cycle \\
\hline
\end{tabular}

one study. ${ }^{21}$ It is clear that the medications commonly used in $\mathrm{CH}$, and indeed in headache, may influence sleep in numerous ways and this area is quite complex (Table 2). ${ }^{13}$ 
Whether the novel CGRP monoclonal antibodies affect sleep is theoretically possible. CGRP antibodies only cross the blood-brain barrier in minuscule amounts $(<1 \%)$ and therefore a direct effect on sleep regulation is unlikely. However, areas not within the blood-brain barrier, including the anterior pituitary gland, choroid plexus, median eminence, area postrema and circumventricular organs, are exposed to the effects of the antibodies. ${ }^{105}$ Consequently, there is a host of indirect pathways through which CGRP potentially could affect sleep but this remains hypothetical.

In the clinic, full polysomnography should be considered for headache patients when there are symptoms potentially associated with sleep disorders. Neither headache nor sleep disorder diagnosis should be delayed as causality cannot be expected and improvement of one is not guaranteed as the other is treated. Treatment and diagnosis should therefore be parallel and not sequential. When that is said, there is evidence from other headache disorders that treating sleep disorders and improving sleep hygiene may improve the headache ${ }^{106-108}$ which may also be the case in $\mathrm{CH}$ where situational insomnia can be seen. ${ }^{49} \mathrm{CH}$ patients should not routinely be referred for cardio-pulmonary monitoring on the suspicion of sleep apnea, as $\mathrm{CH}$ is not an established, independent risk factor. However, patients with other risk factors and symptoms, which is frequent in this patient group ${ }^{75}$ should of course be referred for a proper workup.

With regards to sleep hygiene, $\mathrm{CH}$ patients have been reported to present a high proportion of shift workers ${ }^{20}$ which may be the cause of circadian misalignment. A remedy for this is not straightforward, but maintaining an otherwise normal schedule of diet, exercise and caffeine may be helpful. Hypnotics should be avoided as these may worsen a preexisting headache. ${ }^{109}$ Instead, melatonin with its very high tolerability and possible positive effect on $\mathrm{CH}$ should be used.

\section{Conclusion}

Many aspects of $\mathrm{CH}$ pathology remain unclear and this, together with the severity of the attacks and sparse treatment options, is the reason behind it being a clinical challenge. It is likely that a number of factors may worsen co-existing sleep disorders and with a keen eye on the possible detrimental effects of life-style factors and medication, the role of the clinician should be to ensure optimal treatment of $\mathrm{CH}$ and any possible sleep disorder. Keeping in mind that $\mathrm{CH}$ attack frequency, intensity and rhythmicity are non-static, continuous treatment adjustment and patient education are critically important. Further, high-rigor studies of the possible benefits of applying chronotherapeutic principles in $\mathrm{CH}$ and headache in general are highly warranted.

\section{Funding}

There is no funding to report.

\section{Disclosure}

The author reports no conflicts of interest for this work.

\section{References}

1. Goadsby PJ. Pathophysiology of cluster headache: a trigeminal autonomic cephalgia. Lancet Neurol. 2002;1(4):251-257. doi:10.1016/S1474-4422(02)00104-7

2. Headache Classification Committee of the International Headache Society (IHS). The International Classification of Headache Disorders, 3rd edition. Cephalalgia. 2018;38(1):1-211. doi:10.1177/0333102417738202.

3. Barloese M, Lund N, Jensen R. Sleep in trigeminal autonomic cephalagias: a review. Cephalalgia. 2014;34(10):813-822. doi:10.1177/0333102414537726

4. Burish MJ, Chen Z, Yoo SH. Cluster headache is in part a disorder of the circadian system. JAMA Neurol. 2018;75 (7):783-784. doi:10.1001/jamaneurol.2018.1049

5. Lund N, Barloese M, Petersen A, Haddock B, Jensen R. Chronobiology differs between men and women with cluster headache, clinical phenotype does not. Neurology. 2017;88 (11):1069-1076. doi:10.1212/WNL.0000000000003715

6. Jensen RM, Lyngberg A, Jensen RH. Burden of cluster headache. Cephalalgia. 2007;27(6):535-541. doi:10.1111/j.14682982.2007.01330.x

7. Olesen J, Gustavsson A, Svensson M, Wittchen H-U, Jönsson B The economic cost of brain disorders in Europe. Eur $J$ Neurol. 2012;19(1):155-162. doi:10.1111/j.1468-1331.2011.03590.x

8. Gaul C, Finken J, Biermann J, et al. Treatment costs and indirect costs of cluster headache: A health economics analysis. Cephalalgia. 2011;31(16):1664-1672. doi:10.1177/0333102 411425866

9. Fischera M, Marziniak M, Gralow I, Evers S. The incidence and prevalence of cluster headache: a meta-analysis of population-based studies. Cephalalgia. 2008;28(6):614-618. doi:10.1111/j.1468-2982.2008.01592.x

10. American Academy of Sleep Medicine. International Classification of Sleep Disorders. 3rd ed. Darien, IL: American Academy of Sleep Medicine; 2014.

11. American Academy of Sleep Medicine. International Classification of Sleep Disorders. Westchester, IL, U.S.A: American Academy of Sleep Medicine; 2005.

12. Brennan KC, Charles A. Sleep and headache. Semin Neurol. 2009;29(4):406-418. doi:10.1055/s-0029-1237113

13. Nesbitt AD, Leschziner GD, Peatfield RC. Headache, drugs and sleep. Cephalalgia. 2014;34(10):756-766. doi:10.1177/ 0333102414542662

14. Holland PR, Holland PR. Headache and sleep: shared pathophysiological mechanisms. Cephalalgia. 2014;34(10):725-744. doi: $10.1177 / 0333102414541687$

15. Evers S. Sleep and headache: the biological basis. Headache. 2010;50(7):1246-1251. doi:10.1111/j.1526-4610.2010.01730.x 
16. Barloese MCJ. Neurobiology and sleep disorders in cluster headache. $J$ Headache Pain. 2015;16(1):562. doi:10.1186/ s10194-015-0562-0

17. Lund N, Westergaard ML, Barloese M, Glümer C, Jensen RH. Epidemiology of concurrent headache and sleep problems in Denmark. Cephalalgia. 2014;34(10):833-845. doi:10.1177/ 0333102414543332

18. Loddenkemper T, Lockley SW, Kaleyias J, Kothare SV. Chronobiology of epilepsy: diagnostic and therapeutic implications of chrono-epileptology. J Clin Neurophysiol. 2011;28 (2):146-153. doi:10.1097/WNP.0b013e31821213d4

19. Rozen TD, Fishman RS. Cluster Headache in the United States of America: demographics, Clinical Characteristics, Triggers, Suicidality, and Personal Burden*. Headache. 2011;52 (1):99-113. doi:10.1111/j.1526-4610.2011.02028.x

20. Ofte HK, Berg DH, Bekkelund SI, Alstadhaug KB. Insomnia and periodicity of headache in an arctic cluster headache population. Headache. 2013;53(10):1602-1612. doi:10.1111/head.12241

21. Barloese M, Lund N, Petersen A, Rasmussen M, Jennum P, Jensen R. Sleep and chronobiology in cluster headache. Cephalalgia. 2015;35(11):969-978. doi:10.1177/03331024 14564892

22. Lee MJ, Cho S-J, Park JW, et al. Temporal changes of circadian rhythmicity in cluster headache. Cephalalgia. 2020;40 (3):278-287. doi:10.1177/0333102419883372

23. Koehler PJ. Prevalence of headache in Tulp's Observationes Medicae (1641) with a description of cluster headache. Cephalalgia. 1993;13(5):318-320. doi:10.1046/j.14682982.1993.1305318.x

24. Kudrow L. The cyclic relationship of natural illumination to cluster period frequency. Cephalalgia. 1987;7(Suppl 6):76-78. doi:10.1177/03331024870070S623

25. Manzoni GC, Terzano MG, Bono G, Micieli G, Martucci N, Nappi G. Cluster headache-clinical findings in 180 patients. Cephalalgia. 1983;3(1):21-30. doi:10.1046/j.1468-2982.1983 .0301021.x

26. Russell D. Cluster headache: severity and temporal profiles of attacks and patient activity prior to and during attacks. Cephalalgia. 1981;1(4):209-216. doi:10.1046/j.14682982.1981.0104209.x

27. Horton BT. The use of histamine in the treatment of specific types of headaches. $J$ Am Med Assoc. 1941;116(5):377-383. doi:10.1001/jama.1941.02820050021005

28. Ekbom KA. Ergotamine tartrate orally in Horton's "Histaminic cephalgia" (also called Harris's "Ciliary neuralgia"): A new method of treatment. Acta Psychiatr Scand. 1947;22 (s46):105-113. doi:10.1111/j.1600-0447.1947.tb08104.x

29. Symonds C. A particular variety of headache. Brain. 1956;79 (2):217-232. doi:10.1093/brain/79.2.217

30. Barloese M, Haddock B, Lund NT, Petersen A, Jensen R. Chronorisk in cluster headache: A tool for individualised therapy? Cephalalgia. 2018;38(14):2058-2067. doi:10.1177/ 0333102418769955

31. Li J, Lu W-Q, Beesley S, Loudon ASI, Meng Q-J. Lithium Impacts on the Amplitude and Period of the Molecular Circadian Clockwork. Yamazaki S, ed. PLoS One. 2012;7(3): e33292. doi:10.1371/journal.pone.0033292

32. Leone M, D’Amico D, Moschiano F, Fraschini F, Bussone G. Melatonin versus placebo in the prophylaxis of cluster headache: a double-blind pilot study with parallel groups. Cephalalgia. 1996;16(7):494-496. doi:10.1046/j.14682982.1996.1607494.x

33. Steiner TJ, Hering R, Couturier EG, Davies PT, Whitmarsh TE. Double-blind placebo-controlled trial of lithium in episodic cluster headache. Cephalalgia. 1997;17(6):673-675. doi:10.1046/ j.1468-2982.1997.1706673.x
34. Bussone G, Leone M, Peccarisi C, et al. Double blind comparison of lithium and verapamil in cluster headache prophylaxis. Headache. 1990;30(7):411-417. doi:10.1111/j.1526-4610.1990. hed3007411.x

35. Russell MB. Epidemiology and genetics of cluster headache. Lancet Neurol. 2004;3(5):279-283. doi:10.1016/S1474-4422(04) 00735-5

36. Barloese MCJ, Beske RP, Petersen AS, Haddock B, Lund N, Jensen RH. Episodic and Chronic Cluster Headache: differences in Family History, Traumatic Head Injury, and Chronorisk. Headache J Head Face Pain. 2019;13730. doi:10.1111/ head. 13730

37. Waung MW, Taylor A, Qualmann KJ, Burish MJ. Family History of Cluster Headache: A Systematic Review. JAMA Neurol. 2020;77(7):7. doi:10.1001/jamaneurol.2020.0682

38. O'connor E, Simpson BS, Houlden H, Vandrovcova J, Matharu M. Prevalence of familial cluster headache: A systematic review and meta-analysis. $J$ Headache Pain. 2020;21(1):1. doi:10.1186/s10194-020-01101-w

39. Fourier C, Ran C, Zinnegger M, et al. A genetic CLOCK variant associated with cluster headache causing increased mRNA levels. Cephalalgia. 2018;38(3):496-502. doi:10.1177/033310241 7698709

40. Barloese M, Jennum P, Lund N, Knudsen S, Gammeltoft S, Jensen R. Reduced CSF hypocretin-1 levels are associated with cluster headache. Cephalalgia. 2014;35(10):869-876. doi:10.1177/0333102414562971

41. Rainero I, Gallone S, Valfrè W, et al. A polymorphism of the hypocretin receptor 2 gene is associated with cluster headache. Neurology. 2004;63(1526-1632):1286-1288. doi:10.1212/01. WNL.0000142424.65251.DB

42. Schürks M, Kurth T, Geissler I, et al. Cluster headache is associated with the G1246A polymorphism in the hypocretin receptor 2 gene. Neurology. 2006;66(12):1917-1919. doi:10.1212/01. wnl.0000215852.35329.34

43. Rainero I, Rubino E, Valfrè W, et al. Association between the G1246A polymorphism of the hypocretin receptor 2 gene and cluster headache: a meta-analysis. J Headache Pain. 2007;8 (3):152-156. doi:10.1007/s10194-007-0383-x

44. Weller CM, Wilbrink LA, Houwing-Duistermaat JJ, et al. Cluster headache and the hypocretin receptor 2 reconsidered: A genetic association study and meta-analysis. Cephalalgia. 2014. doi:10.1177/0333102414557839

45. Holland PR, Barloese M, Fahrenkrug J. PACAP in hypothalamic regulation of sleep and circadian rhythm: importance for headache. J Headache Pain. 2018;19(1):20. doi:10.1186/s10194-018-0844-4

46. Bacchelli E, Cainazzo MM, Cameli C, et al. A genome-wide analysis in cluster headache points to neprilysin and PACAP receptor gene variants. $J$ Headache Pain. 2016;17(1):114. doi:10.1186/s10194-016-0705-y

47. Tuka B, Szabó N, Tóth E, et al. Release of PACAP-38 in episodic cluster headache patients - An exploratory study. J Headache Pain. 2016;17:1. doi:10.1186/s10194-016-0660-7

48. Snoer A, Vollesen ALH, Beske RP, et al. Calcitonin-gene related peptide and disease activity in cluster headache. Cephalalgia. 2019:033310241983715. doi:10.1177/0333102419837154.

49. Sahota PK, Dexter JD. Transient recurrent situational insomnia associated with cluster headache. Sleep. 1993;16(3):255-257. doi:10.1093/sleep/16.3.255

50. Nappi G, Ferrari E, Polleri A, Savoldi F, Vailati A. Chronobiological study in cluster headache. Chronobiologia, Vol. 8. ASSOCIATED CHRONOBIOLOGIA RESEARCHERS VIA R. DI LAURIA, 12/A, 20149. MILAN, ITALY. 1981. 140.

51. Barloese M, Jennum P, Knudsen S, Jensen R. Cluster headache and sleep, is there a connection? A review. Cephalalgia. 2012;32 (6):481-491. doi:10.1177/0333102412441090 
52. Manzoni GC, Terzano MG, Moretti G, Cocchi M. Clinical observations on 76 cluster headache cases. Eur Neurol. 2006;66 (12):88-94. doi:10.1159/000115213

53. Dexter JD, Weitzman ED, Dexter JD, Weitzman ED. The relationship of nocturnal headaches to sleep stage patterns. Neurology. 1970;20(5):513-518. doi:10.1212/WNL.20.5.513

54. Kudrow L, McGinty DJ, Phillips ER, Stevenson M. Sleep apnea in cluster headache. Cephalalgia. 1984;4(1):33-38. doi:10.1046/ j.1468-2982.1984.0401033.x

55. Alberca R, Botebol G, Boza F, Navarro A. Episodic cluster headache and narcolepsy: a case report. Cephalalgia. 1991;11 (3):113-115. doi:10.1046/j.1468-2982.1991.1103113.x

56. Pfaffenrath V, Pöllmann W, Rüther E, Lund R, Hajak G. Onset of nocturnal attacks of chronic cluster headache in relation to sleep stages. Acta Neurol Scand. 1986;73(4):403-407. doi:10.1111/ j.1600-0404.1986.tb03296.x

57. Barloese M, Jennum PJ, Lund NT, Jensen RH. Sleep in cluster headache - beyond a temporal rapid eye movement relationship? Eur J Neurol. 2015;22(4):656-e40. doi:10.1111/ene.12623

58. Terzaghi M, Ghiotto N, Sances G, Rustioni V, Nappi G, Manni R. Episodic cluster headache: NREM prevalence of nocturnal attacks. Time to look beyond macrostructural analysis? Headache. 2010;50 (6):1050-1054. doi:10.1111/j.1526-4610.2010.01658.x

59. Nobre ME, Leal AJ, Filho PM. Investigation into sleep disturbance of patients suffering from cluster headache. Cephalalgia. 2005;25(7):488-492. doi:10.1111/j.1468-2982.2004.00897.x

60. Della Marca G, Vollono C, Rubino M, Capuano A, Di Trapani G, Mariotti P. A sleep study in cluster headache. Cephalalgia. 2006;26(3):290-294. doi:10.1111/j.1468-2982.2005.01037.x

61. Zaremba S, Holle D, Wessendorf TE, Diener HC, Katsarava Z, Obermann M. Cluster headache shows no association with rapid eye movement sleep. Cephalalgia. 2012;32(4):289-296. doi:10.1177/0333102411436332

62. Lin J, Suurna M. Sleep Apnea and Sleep-Disordered Breathing. Otolaryngol Clin North Am. 2018. doi:10.1016/j.otc.2018.03.009

63. Myers KA, Mrkobrada M, Simel DL. Does This Patient Have Obstructive Sleep Apnea? JAMA. 2013;310(7):731. doi:10.1001/ jama.2013.276185

64. Barloese MA. Review of Cardiovascular Autonomic Control in Cluster Headache. Headache. 2016;56(2):225-239. doi:10.1111/ head. 12730

65. Wang W, Pan Y, Li Q, Orexin: WL. A potential role in the process of obstructive sleep apnea. Peptides. 2013;42:48-54. doi:10.1016/ j.peptides.2013.01.001

66. Graff-Radford SB, Newman A. Obstructive sleep apnea and cluster headache. Headache. 2004;44(6):607-610. doi:10.1111/ j.1526-4610.2004.446010.x

67. Nobre ME, Filho PFM, Dominici M. Cluster headache associated with sleep apnoea. Cephalalgia. 2003;23(4):276-279.

68. Chervin RD, Zallek SN, Lin X, Hall JM, Sharma N, Hedger KM. Timing patterns of cluster headaches and association with symptoms of obstructive sleep apnea. Sleep Res Online SRO. 2000;3 (3): $107-112$.

69. Chervin RD, Zallek SN, Lin X, Hall JM, Sharma N, Hedger KM. Sleep disordered breathing in patients with cluster headache. Neurology. 2000;54(0028-3878(Print)):2302-2306.

70. Evers S, Barth B, Frese A, Husstedt I-W HS. Sleep apnea in patients with cluster headache: A case-control study. Cephalalgia. 2014;34(10):828-832. doi:10.1177/0333102414544038

71. Buckle P, Kerr P, Kryger M. Nocturnal cluster headache associated with sleep apnea. A case report. Sleep. 1993;16 (5):487-489.

72. Nath Zallek S, Chervin R. Improvement in cluster headache after treatment for obstructive sleep apnea. Sleep Med. 2000;1 (2):135-138.
73. Ranieri ALP, Tufik S, de Siqueira JTT. Refractory cluster headache in a patient with bruxism and obstructive sleep apnea: a case report. Sleep Breath. 2009;13(4):429-433. doi:10.1007/s11325009-0265-3

74. Lund N, Snoer A, Petersen AS, et al. Disturbed sleep in cluster headache is not the result of transient processes associated with the cluster period [submitted]. Eur J Neurol. 2018;1:154.

75. Lund N, Petersen A, Snoer A, Jensen RH, Barloese M. Cluster headache is associated with unhealthy lifestyle and lifestyle-related comorbid diseases: results from the Danish Cluster Headache Survey. Cephalalgia. 2018;033310241878475. doi:10.1177/0333102418784751

76. Krishnan V, Dixon-Williams S, Thornton JD. Where there is smoke ... there is sleep apnea: exploring the relationship between smoking and sleep apnea. Chest. 2014;146(6):1673-1680. doi:10.1378/chest.14-0772

77. Wetter DW, Young TB, Bidwell TR, Badr MS, Palta M. Smoking as a risk factor for sleep-disordered breathing. Arch Intern Med. 1994;154(19):2219-2224.

78. Spałka J, Kędzia K, Kuczyński W, et al. Morning headache as an obstructive sleep apnea-related symptom among sleep clinic patients - a cross-section analysis. Brain Sci. 2020;10:1. doi:10.3390/brainsci10010057

79. Sand T, Hagen K, Schrader H. Sleep apnoea and chronic headache. Cephalalgia. 2003;23(2):90-95. doi:10.1046/j.14682982.2003.00460.x

80. Kristiansen HA, Kværner KJ, Akre H, Øverland B, Sandvik L, Russell MB. Sleep apnoea headache in the general population. Cephalalgia. 2012;32(6):451-458. doi:10.1177/03331024 11431900

81. May A, Bahra A, Büchel C, et al. Hypothalamic activation in cluster headache attacks. Lancet. 1998;352(0140-6736 (Print)):275-278. doi:10.1016/S0140-6736(98)02470-2

82. May A, Ashburner J, Büchel C, et al. Correlation between structural and functional changes in brain in an idiopathic headache syndrome. Nat Med. 1999;5(7):836-838. doi:10.1038/10561

83. Stillman M, Spears R. Endocrinology of cluster headache: potential for therapeutic manipulation. Curr Pain Headache Rep. 2008;12(2):138-144.

84. Leone M, Lucini V, D'Amico D, et al. Abnormal 24-hour urinary excretory pattern of 6-sulphatoxymelatonin in both phases of cluster headache. Cephalalgia. 1998;18(10):664-667.

85. Waldenlind E, Gustafsson SA, Ekbom K, Wetterberg L. Circadian secretion of cortisol and melatonin in cluster headache during active cluster periods and remission. J Neurol Neurosurg Psychiatry. 1987;50(2):207-213.

86. Waldenlind E, Ekbom K, Wetterberg L, et al. Lowered circannual urinary melatonin concentrations in episodic cluster headache. Cephalalgia. 1994;14(3):199-204.

87. Akram H, Miller S, Lagrata S, et al. Optimal deep brain stimulation site and target connectivity for chronic cluster headache. Neurology. 2017;89(20):2083-2091. doi:10.1212/WNL.00000000 00004646

88. Kovac S, Wright M-A, Eriksson SH, Zrinzo L, Matharu M, Walker MC. The effect of posterior hypothalamus region deep brain stimulation on sleep. Cephalalgia. 2013. doi:10.1177/ 0333102413505241

89. Vetrugno R, Pierangeli G, Leone M, et al. Effect on sleep of posterior hypothalamus stimulation in cluster headache. Headache. 2007;47(7):1085-1090. doi:10.1111/j.1526-4610.200 7.00864.x

90. Cortelli P, Guaraldi P, Leone M, et al. Effect of deep brain stimulation of the posterior hypothalamic area on the cardiovascular system in chronic cluster headache patients. Eur J Neurol. 2007;14(9):1008-1015. doi:10.1111/j.1468-1331.2007.01850.x 
91. Malick A, Strassman RM, Burstein R. Trigeminohypothalamic and reticulohypothalamic tract neurons in the upper cervical spinal cord and caudal medulla of the rat. $J$ Neurophysiol. 2000;84(4):2078-2112.

92. Benjamin L, Levy MJ, Lasalandra MP, et al. Hypothalamic activation after stimulation of the superior sagittal sinus in the cat: a Fos study. Neurobiol Dis. 2004;16(3):500-505. doi:10.1016/j. nbd.2004.03.015

93. Spencer SE, Sawyer WB, Wada H, Platt KB, Loewy AD. CNS projections to the pterygopalatine parasympathetic preganglionic neurons in the rat: a retrograde transneuronal viral cell body labeling study. Brain Res. 1990;534(1-2):149-169.

94. Bartsch T, Levy MJ, Knight YE, Goadsby PJ. Differential modulation of nociceptive dural input to [hypocretin] orexin A and $\mathrm{B}$ receptor activation in the posterior hypothalamic area. Pain. 2004;109(3):367-378. doi:10.1016/j.pain.2004.02.005

95. Holland PR, Akerman S, Goadsby PJ. Modulation of nociceptive dural input to the trigeminal nucleus caudalis via activation of the orexin 1 receptor in the rat. Eur J Neurosci. 2006;24 (0953-816X(Print)):2825-2833. doi:10.1111/j.1460-9568.2006 .05168.x

96. Holland PR, Goadsby PJ. Cluster headache, hypothalamus, and orexin. Curr Pain Headache Rep. 2009;13(2):147-154.

97. Cevoli S, Pizza F, Grimaldi D, et al. Cerebrospinal fluid hypocretin-1 levels during the active period of cluster headache. Cephalalgia. 2011;31(8):973. doi:10.1177/0333102411403634

98. Boddum K, Hansen MH, Jennum PJ, Kornum BR. Cerebrospinal Fluid Hypocretin-1 (Orexin-A) Level Fluctuates with Season and Correlates with Day Length. Dominguez JM, ed. PLoS One. 2016;11(3):e0151288. doi:10.1371/journal.pone.0151288

99. Robbins MS, Starling AJ, Pringsheim TM. Treatment of Cluster Headache: the American Headache Society Evidence-Based Guidelines. Headache. 2016;56(7):1093-1106. doi:10.1111/ head. 12866

100. Deen M, Correnti E, Kamm K, et al. Blocking CGRP in migraine patients - a review of pros and cons. J Headache Pain. 2017;18 (1):96. doi:10.1186/s10194-017-0807-1
101. Goadsby PJ, Dodick DW, Leone M, et al. Trial of Galcanezumab in Prevention of Episodic Cluster Headache. $N$ Engl J Med. 2019;381(2):132-141. doi:10.1056/nejmoa1813440

102. Dodick DW, Goadsby PJ, Lucas C, et al. Phase 3 randomized, placebo-controlled study of galcanezumab in patients with chronic cluster headache: results from 3-month double-blind treatment.. Cephalalgia: An International Journal of Headache. 2020;40(9):935-948. doi:10.1177/0333102420905321

103. May A, Leone M, Afra J, et al. EFNS guidelines on the treatment of cluster headache and other trigeminal-autonomic cephalalgias. Eur J Neurol. 2006;13(10):1066-1077. doi:10.1111/j.14681331.2006.01566.x

104. Blau JN, Engel HO. Individualizing treatment with verapamil for cluster headache patients. Headache. 2004;44(10):1013-1018. doi:10.1111/j.1526-4610.2004.04196.x

105. Robbins L. CGRP Antagonists: physiologic Effects and Serious Side Effects. Headache J Head Face Pain. 2018;58 (9):1469-1471. doi:10.1111/head.13408

106. Smitherman TA, Walters AB, Davis RE, et al. Randomized Controlled Pilot Trial of Behavioral Insomnia Treatment for Chronic Migraine with Comorbid Insomnia. Headache. 2016;56 (2):276-291. doi:10.1111/head.12760

107. Calhoun AH, Ford S. Behavioral sleep modification may revert transformed migraine to episodic migraine. Headache. 2007;47 (8):1178-1183. doi:10.1111/j.1526-4610.2007.00780.x

108. de Coo IF, van Oosterhout WPJ, Wilbrink LA, van Zwet EW, Ferrari MD, Fronczek FR. Chronobiology and Sleep in Cluster Headache. Headache. 2019;59(7):1032-1041. doi:10.1111/ head.13567

109. Krystal AD, Erman M, Zammit GK, Soubrane C, Roth T. Longterm efficacy and safety of zolpidem extended-release $12.5 \mathrm{mg}$, administered 3 to 7 nights per week for 24 weeks, in patients with chronic primary insomnia: A 6-month, randomized, double-blind, placebo-controlled, parallel-group, multicenter study. Sleep. 2008;31(1):79-90. doi:10.1093/sleep/31.1.79

\section{Publish your work in this journal}

Nature and Science of Sleep is an international, peer-reviewed, open access journal covering all aspects of sleep science and sleep medicine, including the neurophysiology and functions of sleep, the genetics of sleep, sleep and society, biological rhythms, dreaming, sleep disorders and therapy, and strategies to optimize healthy sleep.
The manuscript management system is completely online and includes a very quick and fair peer-review system, which is all easy to use. Visit http://www.dovepress.com/testimonials.php to read real quotes from published authors. 